\title{
Medya Okuryazarlığı Hareketinde Yedi Büyük Tartışma1
}

\author{
Renee Hobbs ${ }^{2}$ \\ çev.: Melike Türkân Bağlı
}

Son yıllarda, geniș medya okuryazarlı̆̆ uygulamalarda ve müfredat kaynak malzemelerinde bir patlama yaşanmaktadır. Medya okuryazarlığı, büyük çeşitlilik gösteren formlardaki mesajlara ulaşma, bunları çözümleme, değerlendirme ve iletme yeteneği olarak tanımlanmaktadır (Aufderheide, 1993). Bu terim, gittikçe artan sayıda akademisyen ve eğitimci tarafından eleştirel çözümleme sürecine ve kişinin kendi mesajlarını (basılı, işitsel, görsel, çoklumedya ile) yaratmayı öğrenmesine gönderme yapmak için kullanılmaktadır. Bu becerilerin temel olarak okul-temelli ortamlarda ve kitle iletişim metinlerinin kullanılması yoluyla öğrenilmesine ve öğretilmesine vurgu yapılmaktadır (Alvarado, Gutch ve Wollen, 1987; Brown, 1991; Hobbs, 1994a; Piette, 1997). Buna karşın medya okuryazarlığı, geniş tanımı ve uygulama kapsamı, ilgi uyandırıcı çatışmalar ve gerginlikler yaratan çeşitli yaklaşımlara yol açan bir kavramdır. Tyner (1992), Amerika Birleşik Devletleri'nde ortaya çıkan medya okuryazarlığı hareketi ile her biri bütünün küçük bir parçasını algılayan kör adamlar ve fil meseli arasında bir paralellik kurmuştur. Ardalanları medya incelemeleri, güzel sanatlar, sahne sanatları, tarih, psikoloji, sosyoloji, eğitim ve edebiyat çözümlemeleri olan eğitimcilerin ve akademisyenlerin her biri, medya metinlerine ulaşmanın, bunları çözümlemenin, değerlendirmenin ve/ya da yaratmanın ne demek olduğuna ilişkin kendi anlayışını, çeşitli diğer yaklaşımların karmaşıklık, derinlik ya da bütünlük derecelerinden tamamen habersiz olarak, güçlü bir biçimde savunabilmektedir. $\mathrm{Bu}$ çeşitliliğin yarattığı husumeti açıklamak üzere, New Mexico'daki Albuquerque Akademisi'nde öğretmen ve New Mexico Okuryazarlık Projesi'nin lideri olan Bob McCannon, St. Louis'de Nisan 1996'da Kültürel Çevre Hareketi anlaşmasının oluşturulması sırasında, "medya okuryazarlığı eğiticilerinin ne zaman biraraya gelseler, vagonları döndürdüklerini ve ondan sonra da onlara ateş ettiklerini” belirtmektedir.

Eğitimciler arasında bakışaçılarının çeşitliliği, ortaya çıkan medya okuryazarlığı hareketi için bir güç kaynağı olarak mı hizmet etmektedir, yoksa temel olarak, medya okuryazarlığ 1 gibi genişletici ve istikrarsız bir kavramı tanımlama ve yayma çabalarının problematik doğasını mı göstermektedir?

\footnotetext{
${ }^{1}$ Hobbs, R. (1998). The seven great debates in the media literacy movement. Journal of Communication, 48(1), 16-32

${ }^{2}$ Renee Hobbs (EdD, Harvard Üniversitesi, 1985) Babson Koleji’nde iletişim alanında doçent, Clark Üniversitesi'nin Hiatt Kentsel Eğitim Merkezi'nde (Hiatt Center for Urban Education) yürütülen Medya Okuryazarlığı Projesi'nin de yöneticisidir. Hobbs, medya incelemeleri alanında ders vermektedir ve medya eğitimi konusunda öğretmen eğitimleri düzenlemektedir. Renee Hobbs, Clark Üniversitesi'nden Sarah Michaels ve Bob Neill'e, 1996-1997 akademik yılında yütrüttüğü araştırması sırasındaki destekleriden dolayı teşekkür etmektedir. ${ }^{3}$ Dr. Ankara Üniversitesi Eğitim Bilimleri Fakültesi’nde Araştırma Görevlisi
} 
Medya eğitimcileri biraraya geldiklerinde ortaya çıkan gerilimler, eğitimcilerin ulusal ve bölgesel düzeyde projelerde işbirliği yapma yeteneklerini sinırlandırabilmektedir. Örneğin 1995 'de, Massachusetts'den bir grup eğitimci, akademisyen, sanatçı ve eylemci, Massachusetts Medya Okuryazarlığı Koalisyonu'nu (Massachusetts Coalition for Media Literacy) kurmak için biraraya gelmişlerdir. Devlet televizyon istasyonu WGBH'de düzenlenen ve Massachusetts Beşeri Bilimler Vakfi'nın (Massachusetts Foundation for the Humanities) ev sahipliği yaptığı bir dizi toplantıda, çeşitli hedeflerin, güdülerin ve öğretimsel uygulamaların doğurduğu çatışmalar açığa çıkmıştır. Bazı kişiler, bazı katılımcıların yorumlarında dile getirilen medya karşıtı yaklaşıma ("öldür televizyonunu”) öfkelenmişlerdir. Bazı akademisyenler, öğretmenlerin ve kâr amacı gütmeyen grupların temsilcilerinin düşüncelerinin yapay ve kuramdan yeterince yararlanmamış olduğunu düşünmüş̧lerdir. Bazı araştırmacılar, eleştirel eğitim hedefinin, gençlerin medya mesajlarına sağlıksız bağımlılıklarını tersine çevirmek ve onları, ilgilerini alternatif medya sanatlarına yöneltmeleri için ikna etmek olduğuna inanırken, diğerleri kitle iletişim tüketimini, çocukluğun ve ergenliğin doğal ve gelişimsel olarak normal bir parçası olarak değerlendirmişlerdir.

Medya eğitimi yaklaşımlarının, felsefelerinin ve hedeflerinin çeşitliliği, medya incelemeleri ile eğitim alanlarının kesişme noktasında doğmakta olan bir alan için kaçınılmaz bir sonuçtur. $\mathrm{Bu}$ alan, sonunda, devlet okullarının laboratuvarlarında gerçekleşen deneylerin bir sonucu olarak süzülmeye (damıtılmaya) başlamıştır.

Belki de büyük tartışmalar, sıklıkla dar bir çerçeve içinde oluşturulmuş parametrelerle, çıkarların ve düşünsel kliklerin rekabetine sahne olan, bölünmüş ve ikonoklastik altkültürlerin varlık gösterdiği eğitim çevresi için bir kârdır.

1996'da, Los Angeles'daki Ulusal Medya Okuryazarlığı Konferans1, lise İngilizce öğretmenlerini, üniversite hocalarını, metin yazarlarını, çocuk televizyonu savunucularını, halk sağlığı uzmanlarını, ilköğretim öğretmenlerini, iletişim siyasa uzmanlarını, video sanatçılarını ve müzisyenlerini, dinsel eğitim cemaati üyelerini, ortaöğretim sağlık öğretmenlerini, gençlik savunucularını ve teknoloji uzmanlarını, geniş bir yelpaze içerisinde seslerin ve görüşlerin duyulduğu üç günlük bir toplantıda biraraya getirmiştir. Böyle bir perspektif çeşitliliği, kavramın açık tanımı ve geniş alanı, medyayı eleştirel bir biçimde çözümleme ve yaratma konularına gençlerle çalışmaya duydukları ortak ilgi tarafından bağlanmış olan (çoğunlukla akademi dışından) bireyleri biraraya getirmeye hizmet ettikçe, medya okuryazarlığına artan ilgiyi besleyen bir motor olabilir.

1980'ler boyunca, dünyada medya okuryazarlığının ufkunu daraltacak ve tanımlayacak pek çok çaba sözkonusu olmuştur (Bazalgette, 1992b; Bazalgette, Bevort ve Savino, 1991; Bertelsmann Foundation, 1993, 1994; Quin ve McMahon, 1995). Bu gelişmelerin bir sonucu olarak, eğitimciler, medya metinlerinin sınıfta kullanıldığı zamanlarda incelenecek temel öğretimsel noktalar olan kilit kavramlar üzerinde anlaşmaya başlamışlardır. 1993 Medya Okuryazarlığı Ulusal Liderlik Konferansı'nda, Amerikalı eğiticimler, medya eğitimi için uygun hedeflerin uzamı ya da uygun öğretim tekniklerinin genişliği konusunda anlaşmaya varamamışlardır; ancak İngiliz, Avustralyalı 
ve Kanadalı eğitimciler tarafından geliştirilen modellere dayanarak aşağıdaki kavramların medya mesajları çözümlemesine dahil edilmesi gerektiğini belirlemişlerdir:

1. Medya mesajları kurgulanmıştır/ kurulmuştur (constructed).

2. Medya mesajları, ekonomik, sosyal, siyasal, tarihsel ve estetik bağlamlar içerisinde üretilir.

3. Mesaj alımlamaya dahil olan yorumlayıcı anlam-yapma süreçleri, okuyucu, metin ve kültür arasındaki etkileşime dayanır.

4. Medyanın kendine özgü "dilleri” ve çeşitli biçimlerle, türlerle (genres) ve iletişim simge sistemleriyle sembolleşen karakteristikleri vardır.

5. Medya tasarımlamaları, insanların sosyal gerçekliği anlamalarında rol oynar (Aufderheide, 1993, s. 2).

1993 yılında bu anahtar kavramların oluşturulmasıyla yaratılan sözbirliği, ulusal düzeyde farklı coğrafi bölgelerden, eğitsel ardalanlardan ve uzmanlık alanlarından gelen akademisyenlerin ve eğiticilerin katıldığı öğretmen eğitimi programlarının düzenlenmesini mümkün kılarak, Amerikan medya eğitimcileri arasında işbirliği etkinliklerinin artmasına yol açmıştır (Hobbs, 1994b). Medya eğitiminin tanımına ve temel analitik çerçeveye ilişkin bir sözbirliğinin doğması, son beş yılda üretilen kaynak malzemenin miktarındaki ve ülkedeki öğretmen eğitim programlarının niteliğindeki artışa eşlik etmiştir.

Bu makalede, Amerika Birleşik Devletleri’nde medya okuryazarlığı eğitimini, okul içinde ve dişında, ilk ve orta dereceli okul öğrencileri üzerinde uygulayan çeşitli eğitimci, eylemci ve akademisyen grupları arasında hâlâ süregiden tartışmaların altında yatan sorulardan bazılarını gözden geçirmekteyim. Burada belirlenen yedi soru, tabii ki tartışılan bütün konuları kapsamamaktadır. Ancak bu makalede belirlenen büyük tartışma konuları, temeldir; yani, bu yedi soru, uygulamacılar için halihazırdaki sorgulama alanını belirlemektedir. Çeşitli eğitim felsefelerine ilişkin bir sorun örneklemi olarak, bu makalede belirlenen "büyük tartışmalar" temelde, açıç̧a ya da gizil olarak medya hakkında ya da medyayla eğitim yapan eğitimcilerin sınıf uygulamalarına yön veren çerçeveleyici sorularıdır.

\section{Yedi Tartışma}

\section{Medya Okuryazarlı̆̆ı Ĕ̆itimi Çocukları ve Gençleri Medyanın Olumsuz Etkilerinden} Korumayı Amaçlamalı mıdır?

Medya okuryazarlığı ile ilgilenen eğitimciler, muhakeme ve iletişim becerilerini geliştirmeyi (Brunner ve Smith, 1994; Hobbs, 1996), 1rk, sinıf ve toplumsal cinsiyet eşitsizlikleri ile yüzleşmeyi (Eriksen-Terzian, 1992), demokrasi, yurttaşlık ve siyasal katılıma yönelik tutumları geliştirmeyi (Carnes, 1996; Jospin, 1992; Landa, 1992; Morduchowitz, 1997; Newspaper Association of America, 1995; Sandroni, 1992), 
iletişim siyasası ve/ya da medya endüstrisi uygulamalarını yeniden biçimlendirmeyi (Center for Media Education, 1997; Kumar, 1992), kişisel gelişimi kolaylaştırmay1 (Mendez ve Reyes, 1992), gençler arasındaki madde kullanımını ve şiddeti önlemeyi (Carnegie Council of Adolescent Development, 1995; Gorley, 1997; ONDCP, 1996), meslek becerilerini artırmayı (Freedom Froum, 1994), inanç ve toplumsal adalet sorunlarını gündeme getirmeyi (Center for Media Literacy, 1993; Mahony, 1992), materyalizm ve kültürün metalaştırılması konularında farkındalığı telkin etmeyi (Boihem ve Emmanouildes, 1996; Citizens for Media Literacy, 1993) ve eğitimin niteliğini iyileştirmeyi (Dichanz, 1995; Hobbs, 1998c; Piette ve Giroux, 1996) içeren, geniş bir çeşitlilikteki hedefleri, güdüleri ve amaçları benimseyebilirler ve benimsemektedirler.

Anababaların popüler kültürü temsil eden "basit yığını"na ("avalanche of crud") ilişkin kaygıları, yetişkinlerin, çocukların medya erişimlerini denetleme yetersizlikleriyle ilgili genel kaygıyla birlikte son yıllarda yeniden canlanmış durumdadır (Denby, 1996). Medya okuryazarlığını, medyanın gençlik üzerindeki olumsuz etkisini azaltmak yönündeki gücünü vurgulayarak haklılaştıran koruyucu bakışaçısı, en çok, doğrudan doğruya okul ortamında çalışmayanlar arasında yaygındır (DeGaetano ve Bander, 1996). Ayrıca, bu duruş, sırf anababalara ve toplum üyelerine medya okuryazarlığ önemini ifade etmedeki retorik değerinden dolayı sık sık kullanılmaktadır.

"Çocuklara medya metinlerini yapıbozuma uğratmaları (deconstruct) öğretilebilirse, sihirli 'mantra' gider ve o zaman çocuklar, fantazi tarafından aldatılmaz, şiddet tarafından sömürülmez ya da ticari niyetler tarafından manipüle edilmezler. $\mathrm{Bu}$ senaryoya göre, medya eğitimi, tetanoz aşısının pedagojik muadilidir" (Bazalgette, 1997, s. 72).

Anderson (1983) etki aracılığ yaklaşımının, içeriği genel olarak, şiddet, materyalizm, beslenme, beden imgesi, risk alma davranışları, habercilikte çarpıtma ve yanlılık, 1rk, sınıf, toplumsal cinsiyet ve cinsel kimlik kalıpyargıları geliştirme gibi problem alanları etrafında örgütlediğini belirtmektedir. Birleşik Devletler'de, pek çok eleştirmen, halk sağlığı çalışanları ve akademisyenler, medyaya maruz kalmayı bir risk faktörü olarak belirlemekte ve medya okuryazarlı̆̆ını da koruyucu faktör olarak önermektedirler. Son kanıtlar, medya okuryazarlığı eğitiminin küçük çocukların alkol hakkındaki karar verme davranışlarını etkileyebildiğini göstermektedir (Austin ve Johnson, 1997).

Medya okuryazarlığının, gençleri medyanın olumsuz etkilerinden koruyabileceğine ilişkin iddia, pek çok eğitimci ve akademisyen için sorunludur ve İngiltere'de bu bakışaçısı, bu tür yaklaşımların seçkinci olduğuna ve sosyal bilim araştırmalarına zayıf bir biçimde dayandığına inanan akademisyenler tarafından kısmen alaya alınmıştır (Collins, 1992; Halloran ve Jones, 1992; Hart, 1997). Sosyal bilim araştırmalarının, medya okuryazarlığı eğitiminin gençleri medyanın olumsuz etkilerinden koruduğunu göstermeleri mümkün olsun ya da olmasın, bu eğitimciler, pedagojik 
zemindeki koruma söylemine karşı çıkmaktadırlar. Bu görüşe göre, kendilerinin öğrenciyi koruduğunu düşünen eğitimcilerin ortaya koyduğu öğretim yöntemleri sinıfta etkili değildir. Medya okuryazarlığı becerileri, medya kültürünün karşısında konumlandırıldığında, öğretimin niteliği tehlikeye girmektedir. İlk ve orta öğretimle üniversite düzeyindeki birçok öğretmen, öğrencilerin, medya etkisine yenik düşen kurbanlar oldukları ve popüler kültüre olan ilgilerinin ölçüsüzlügünden ve kötülüğünden kurtarılmaları gerektiği fikrine tepkisiz kaldıklarını bulmuşlardır. Buckingham (1993), kitle iletişiminin sorunlu özelliklerine odaklanarak, gençlerin, medya ile duygusal bir ilişki içine girdiklerini gözden uzak tuttuğumuzu ve gerçek sorgulama ve analizi teşvik etmek yerine şüpheciliği ve üstünlüğü koyarak, onların elde ettikleri gerçek hazları göz ardı edebileceğimizi iddia etmektedir. Koruyucu yaklaşım, genellikle öğretmenin öğrenciye medyanın olumsuz etkileri hakkındaki "gerçekler"i ve mesajların manipülasyonunu anlattığı ve öğrencinin sessizce dinlediği ve sınav için not tuttuğu öğretici odaklı bir sınıfa yol açmaktadır. Öğretmeye ve öğrenmeye bu türlü bir yaklaşım, öğrencilerin doğru yorumları -öğretmenin izin verdiklerini- papağan gibi tekrarlamasına neden olabilir ve böyle olunca da, medya okuryazarlığı eğitimi, otantikliğini ve öğrencilerin yaşamlarıyla olan bağını kaybedebilir (Buckingham 1990; Masterman, 1985; Williamson, 1981).

\section{Medya Üretimi Medya Okuryazarlığı Ĕ̆itiminin Temel Bir Özelliği Olmalı mıdır?}

Bazı eğitimciler, gençlerin, fotoğraf çekmek, öykü kareleriyle (storyboard) düşünceleri planlamak ve organize etmek, metinler yazmak ve kamera önünde oynamak, kendi internet sayfalarını tasarlamak veya bir haber öyküsünü bildirmek deneyimlerini yaşamadıkça kitle iletişiminin gerçek anlamda eleştirel tüketicileri haline gelemeyeceklerine inanmaktadırlar. "Teknolojinin gücü, öğrenciler teknolojiyi kendi çalışmalarının yaratıcıları olarak kendi elleriyle kullanabildiklerinde ve ondan eleştirel sorgulama, kendini yansıtma ve yaratıcı anlatım için yararlandıklarında serbest kalır" (Goodman, 1996; s. 2). Bu görüşe göre, medya okuryazarlı̆̆ 1 , öğrenciler medya metinlerini okuma kadar pek çok yazma deneyimi de yaşamadıkça eksik kalır. İngiltere'de, medya üretimi çalışmaları etkin bir biçimde öğrenci becerilerini değerlendirmek için kullanılmaktadır (Stafford, 1992). Kanada'da öğrenci çalışmalarından beklenenlerin bir parçası olarak medya üretimi etkinlikleri de ele alındığından, öğretmenlere bu konuda yardımcı olmak için öğrencilerin yarattığı medya ürünlerini değerlendirmede kullanılacak kriterler sağlanmış durumdadır (Worsnop, 1996).

Eğitimciler, medya üretimini sınıftaki etkinliklere dahil etme çabalarını, genellikle şu iki kategoriden birinde değerlendirmektedirler: Anlatımsal veya mesleki (Fraser, 1992; Lambert, 1997). Anlatımsal medya üretimini savunan eğitimciler, genellikle kişinin kendi sesini keşfetmesinden kaynaklanan yararları öne çıkarmakta 'güçlendirme' dilini kullanarak öğrencilerin yaratıcı becerilerinin güçlendirilmesini vurgularlar. Mesleki medya üretimini vurgulayan eğitimciler, işbirliği içeren takım çalışmasının değerini, medya üretiminin bir endüstri olarak gelişimini ve geleneksel 
olmayan pek çok öğrenicinin, görsel düşünme, planlama, düzeltme, sergileme ya da yönetme ile ilişkili olan bu görevlerde kendisini gösterebileceğini sık sık vurgularlar (Lusted, 1991; Stafford, 1992).

Yine de birçok eğitimci, akademisyen ve anababa, öğrencilerin video üretirken ya da haber öyküleri yazarken gerçekten ne öğrendiklerini merak etmektedir (Grahame, 1991). Uygulama çalışmalarıyla ilgili en büyük kaygı, medya üretiminin, öğrencilere sınırlı bir dizi becerinin (Hollywood'un ya da haber endüstrisinin hiyerarşisini sadece yeniden üreten becerilerin) bağlamdan uzaklaşmış bir görevler dizisi olarak kolaylıkla öğretilebileceğine ilişkin korku çevresinde yoğunlaşmaktadır. Bu görüşe göre, çocuklara ve gençlere medya üretimini öğretmek, gerçekte kültürel olarak değerli olan okuma ve yazma becerilerini öğrenmekten uzaklaşmış olan öğrencileri, “iş becerileri”ni öğrenecekleri iddiasıyla çeken sahte türde bir mesleki eğitimdir. "Uygulama çalışmalarının büyük tehlikesi, [...] öğrencilerin basitçe profesyonelleri taklit etmeyi öğrenecekleri ve eleştirel ve analitik bir çerçevenin kaybolacağıdır" (Stafford, 1990, s. 81). Bu eleştiriler, artan bir biçimde, suçu iletişim alanındaki üniversite programlarında bulmaktadir (Davies, 1996).

Birçok üretim etkinliğinin uygulamaya ilişkin kısıtlılıkları, bunların ilk ve orta dereceli okul öğrencilerine önerilmesini önlemektedir. Örneğin, video ve çoklumedya üretimleri, genellikle halihazırda pek çok okulda sağlanandan daha fazla donanım, ders süresi, personel ve öğretmen eğitimi gerektirmektedir. Tarihsel olarak, birçok okulda, video üretimi, İngilizce ve mesleki eğitim müfredatlarında Buckingham'in (1993) söylediği biçimde "başarı altında kurumsallaşmış" (s. 284) en düşük düzeydeki düzlem olarak kullanılagelmiştir. Bu okullarda, yüksek düzeyde yetenekli öğrenciler, daha geleneksel basılı materyallere dayalı eğitim alırken, düşük düzeyde yeteneğe sahip öğrencilerin, video temelli bilgisayar teknolojileri ile "oynamaları"na izin verilmiştir. Birçok Amerikan okulunda ve bazı Avrupa okullarında, medya üretimi, okuldan ayrılmadan önce medya üretiminin son firsat olduğu okur olmayanlar veya düşük düzeyde yetenekli yahut da davranış problemleri olan öğrencilere özgü alanı oluşturmaktadır (Bazalgette, 1993; Bevort ve Thierry, 1997; Fraser, 1992; Hobbs, 1994a). $\mathrm{Bu}$ uygulamalar, bazı eğitimcilerin medya üretimi etkinliklerini, medya okuryazarlığı becerilerini okulların entellektüel hiyerarşisinde daha yüksek bir bağlama yerleştirmek için kaçınılmaz olarak "baypas" etmelerine yol açmaktadır.

\section{Medya Okuryazarlı̆̆ Popüler Külttür Metinlerine Odaklanmalı mıdır?}

Medya okuryazarlığının popüler kültür medya metinlerine odaklandığı açık bir biçimde görünebilir, ancak ilk ve orta dereceli okullar bağlamında, sınıfta popüler medya metinlerini kullanmanın değeri ve tuzakları hakkında ciddi bir tartışma vardır (Greenaway, 1997; Hart, 1997). "Okullar, her düzeyde, elektronik şekilde iletilen formları da dahil olmak üzere, popüler kültürün değerini azaltmak için kurulmuştur" (Aronowitz ve Giroux, 1991, s. 153). Popüler kültür metinleri, sinıftaki rutini zorlayabilir ve bozabilir ve öğrencilerin öğrenme ve iletişimde sözkonusu olan süreçlere ilişkin 
gelişmekte olan anlayışlarıyla ilişkili epistemolojik konuları tartışmaları için öğretmen ve öğrencilere fırsatlar sağlar (Dewing, 1992; Giroux, 1994). Bu görüşe göre, gündelik yaşam metinleri, toplumsal bilgi nesneleri olarak kurulduklarında, öğrenci ve öğretmenlere geleneksel disiplinlerin ve konu alanlarının sınırları ötesine geçmelerinde yardımcı olacak biçimde, metinsel, tarihsel ve ideolojik analizleri birleştirmek için olanaklar sağlarlar.

Ancak diğer eğitimciler, ortalama bir anababanın, 10. sınıftaki kızı ya da oğlu okuldan eve gelip The Simpsons'1 Mark Twain'in kısa bir öyküsüyle karşılaştırdıkları dersi anlatmaya başladığında nasıl bir tepki vereceğini merak etmektedirler. Aslında, eğitimciler, bu tür metinlerin yapıbozuma uğratılması deneyiminin, öğrencilerin, edebi çalışmalara yönelik ilgilerini güdüleyebildiğine ilişkin gözlemlerini vurgulayarak, The Simpsons'in bölümlerini taşlama ve parodi türlerini (genres) ele almak için kullanmaktadırlar (Fraser, 1992; Hobbs, 1998b).

Bilginin toplumsal olarak kurulduğunu anlamak, medya okuryazarlığı için büyük ve temel bir katkıdır. Bazı medya eğitimcilerine göre, bu ve diğer medya okuryazarlığ kavramları, Beavis ve Butthead yakından değerlendirilerek öğrenilebileceği gibi, edebiyatın ve sinemanın klasik eserlerinin analiz edilmesi yoluyla da öğrenilebilir. 1995'de, Kuzey Carolina'da 300'den fazla eğitimci için düzenlenen bir öğretmen eğitimi programında, katılımcılar arasında, bir içecek reklamının sınıfta bir inceleme konusu olarak kullanılıp kullanılamayacağı konusunda ateşli bir tartışma çıkmıştır. Öğretmenlerden biri, medya okuryazarlı̆̆ ders kitaplarındaki fotoğraflar ve New York Times gibi ulusal gazeteler kullanılarak etkili bir biçimde öğretilebileceğini vurgulamıştır. Başka bir öğretmen, öğrencilerin televizyonda binlerce reklama, yüzlerce filme ve durum komedisine maruz kaldıkları gerçeğini ortaya koymuştur. $\mathrm{Bu}$ öğretmenin görüşüne göre, öğrenciler, genel izleme yaşantılarının parçası olan metinleri analiz etme uygulamalarına ihtiyaç duymaktadırlar. $\mathrm{Bu}$ tartışmanın temelinde, edebiyatta görece araştırılmamış temel bir görgül soru yatmaktadır: Medya okuryazarlığı becerileri ne dereceye kadar bir türden (genre) diğerine, ya da bir simgesel formdan bir başkasına aktarılır?

Medya okuryazarlığı eğitiminde popüler kültür vurgusu, geniş bir biçimde, bu eleştirel düşünme biçimini, bilgi (information) okuryazarlığını, bilgisayar okuryazarlığını ve yazım (print) okuryazarlığını içeren ilişkili diğer kavramlardan neyin ayırdığıdır (Masterman, 1997; McClure, 1996; Piette, 1997; Tyner, baskıda). Bazı eğitimciler, eğer becerilerin okuldan eve aktarılması amacı istendik bir sonuçsa, medya okuryazarlığının merkezi bir biçimde, öğrencilerin ilk müfredatının merkezindeki -evde televizyon izleme, kişisel medya tüketimi yaşantıları- popüler kültürel metinlerle bağlantılı olması gerektiğine inanmaktadırlar. 


\section{Medya Okuryazarlı̆̆ının Daha Doğrudan bir Politik ve İdeolojik Gündemi Olmalı mudir?}

Eğitimciler, medya okuryazarlı̆̆ının, devlet okullarındaki katı kurumsal uygulamaları değiştirmek, okullarda ticari sponsorluklarla gerçekleşen medya kullanımını durdurmak, devlet televizyonuna, yerel erişime veya alternatif medya sanatlarına desteğin artırılması ve medya sahipliği ile ilgili olarak yayın ve kablo değişiklikleri yapmak gibi bir dizi ilerlemeci politik amacı gerçekleştirmek için hizmet edebileceğini öne sürmüşlerdir. Ancak, diğer öğretmenler, medya okuryazarlığı uygulamalarını, öğrencilerin $1 r k c ̧ 11$ k, cinsiyetçilik, şiddet ve homofobiye ilişkin tutumlarındaki toplumsal değişimleri hızlandırma aracı olarak kullanmayı amaçlayabilmektedirler.

Medya öğretmenleri, kendilerini, sık s1k, "neşeli eğlencelerin bir parçası gibi görünen imgelerin, filmlerin ya da programların sizi ideolojik olarak manipüle etmeyi nasıl amaçladığını göstererek kapitalizmin kendini dev aynasında gören sayıltılarının ve ince kesinliklerinin foyasını meydana çıkaranlar" (Bazalgette, 1992b, s.141) olarak görmektedirler. Çünkü medya okuryazarlı̆̆ pedagojisi, mesajların nasıl kurulduğuna ilişkin soruları davet eder; eğitimciler haklı olarak, mesaj üretiminin ve mesaj tüketiminin çevresindeki güç dinamiklerini araştırmanın anlamlı politik ve sosyal eylemler için firsatlar yarattığını belirtirler. Ancak bir dizi siyasa lideri, medya okuryazarlığ becerileriyle sosyal ve politik savunuculuk arasında doğrudan temas olmaksızın, medya okuryazarlığının eylemi teşvik etmekten çok, eylem yerine geçen bir olgu olarak yozlaşabileceğine ilişkin korkularını dile getirmektedirler (K. Montgomery, kişisel görüşme, 24 Nisan 1997).

Diğer eğitimciler, medya okuryazarlığını eğitim sistemine radikal değişiklikler getirmek için bir potansiyel olarak görmektedirler. Bazı akademisyenlere ve eğitimcilere göre, sınıftaki güç ilişkileri, müfredatın içeriğini, öğrencilerin uzman oldukları, öğretmenlerin ise hakkında pek az şey bildikleri konuları (örneğin, popüler kültür) içerecek şekilde değiştirmek yoluyla ortadan kaldırılabilir (Giroux, 1994). Medya okuryazarlığ yapılandıran kültürel kodları belirlemeye, bu kodların sosyal sistemin parçası olarak nasıl işlevde bulunduğunu anlamaya ve metni alternatif yorumlarla parçalamaya davet eder (Scholes, 1987). Bu görüşe göre, medya okuryazarlı̆̆1, "eleştirel yurttaşların yaratımını radikal demokrasinin gelişimine bağlayan" postmodern politik projenin bir parçasıdır (Aronowitz ve Giroux, 1991, s. 188).

Ancak Buckingham (1993), bu çabaların riskleri konusunda uyarıda bulunmaktadır:

Öğrenciler, öğretmenlerin ... propagandacı yaklaşımlarına bir iki yönde tepki verebilirler. Ya kendi konumlarını tam olarak değerlendirip sorgulamadan "siyaseten doğru" cevapları yeniden üretmeyi öğrenebilecekleri oyunu oynamayı seçecekler, ya da inanabilecekleri ya da inanamayacakları şeyler söyleyecekleri 
durumlarda öğretmeni kızdırmak ve dolayısıyla kendilerini eğlendirmek için bunu yapmayı reddedeceklerdir. (s. 290).

Radikal eğitimcilerin endişesine rağmen, medya okuryazarllğg kavramları ve öğretim uygulamaları, birbirinden farklı çeşitli politik inançlara sahip kişiler için çekicidir. Bazı muhafazakârlar, medya eğitimini birkaç şekilde değerlendirmektedir: Bireysel eyleme odaklanan bir sosyal değişme biçimi olarak (Tauzin, 1997), basının liberal yanlılıklarına karşı çıkacak bir araç olarak ya da medyaya yönelik olarak hükümetin aşırı düzenlemelerine bir alternatif olarak (Lemish ve Lemish, 1997).

Dewey'in eğitimin sosyal ilerlemenin ve reformun temel yolu olduğuna ilişkin iddiasını kabul eden eğitimciler, hâlâ medya okuryazarlığı ile ilgili bilgi, beceri ve tutumların basit bir biçimde başka amaçlara götüren araçlar olarak değil, bağımsız hedefler olarak anlaşılması gerektiğine inanmaktadırlar. Birçok öğretmen, kendilerini radikal sosyal ve politik değişime yol açacak güçler olarak görmez (Cremin, 1990). Aksine, öğretmenler, kendi üzerine düşünme, eleştirel analiz ve kendi amaçları ve güdüleri için iletişimde bulunma araçlarını içselleştirme süreci olan öğrencilerin eleştirel bağımsızlıklarını geliştirme kavramına genel olarak değer verirler (Mendez ve Reyes, 1992). Bu görüşün altında yatan çoğulculuk, öğretmenleri, öğrencilerin keşfetme potansiyellerini ve belirli bir gündemi öğrencilere dayatmadan, kişisel, sosyal ya da politik eylemlerin gerçekleştirilmesini en üst düzeye çıkartmaya davet eder.

$\mathrm{Bu}$ görüşe göre, medya eğitimi, öğretmenin medyaya ilişkin görüşlerinin yeniden üretimine indirgenmemelidir (Masterman, 1997). Bu hedef, birçok Amerikan üniversitesinde medya incelemelerinin öğretilme biçimi ile kesin bir zitlık gösterir. Medya okuryazarlı̆̆ 1 eğitiminin en temel ilkelerinin (öğrencilere metinsel otoriteyi sorgulamayı ve özerk kararlara varabilmeleri için muhakemeyi kullanmayı öğretmek) arkasında bile açık bir ideoloji bulunur. Bu gündem, daha açık bir biçimde formüle edilmiş diğer politik ve sosyal değişme hedefleriyle ilişkili ek yükler yüklemeksizin, yeterince radikaldir (Lemish ve Lemish, 1997). Ek sosyal ve politik değişim hedefleri, yaygın kamu eğitiminin merkezilikten uzaklaşmış, politik olarak bölünmüş ve topluluk (community) merkezli ortamında pek kabul edilebilir gibi değildir.

\section{Medya Okuryazarlı̆̆ı Okul Temelli İlk ve Orta Ö̆̆retim Ĕğitim Ortamlarına Odaklanmalı midır?}

Medya okuryazarlığına ilişkin pek çok akademik ve popüler yazı, okullara, çocuklara, öğretmenlere ve kamu eğitimine çok az gönderme yapmaktadır (Bianculli, 1992; Messaris, 1996; Silverblatt, 1996; Singer ve Singer, 1983). Bazı eğitimciler medya okuryazarlığ (Axelrod, 1997). Okullar, paradoksal bir biçimde, hem en radikal hem de en tutucu sosyal kurumlardır (Maehr ve Midgely, 1996) ve okullar, okulların misyonuyla medya ve bilişimin rolü arasındaki uygun ilişkiyi tarif etmekte çok bilinen bir şekilde sessiz kalmış durumdadırlar (Sizer, 1995). Daha önce açıklandığı gibi, medya okuryazarlığından 
beklenen amaçların, hedeflerin ve sonuçların çeşitliliği, doğal olarak okullardaki çalışmaların etkililiğini sınırlandırmaktadır.

Medya okuryazarlığı öncüleri, en çok başarıyı, öğretmenlerin, anababaların ve öğrencilerin, medya kültürü ile ortak ve paylaşılan bir aşk-nefret ilişkisi vizyonunun olduğu okul topluluklarında göstermişlerdir. Medya okuryazarlığını okula dahil etmeye ilişkin en başarılı çabalar, okul bölgesindeki öğretmenler ve okul liderleri arasında sınıf uygulamalarıyla ilişkisi kuruldukça açıklığa kavuşacak biçimde tanımlanan bir kavram anlayışını oluşturmak için, personel geliştirme etkinliklerinin yapıldığ fazla bir süreyi almıştır. (Brown, 1991; Hobbs, 1998a; Hobbs ve Frost, 1997). 1970’lerde eleştirel izleme becerilerini öğretmeye dönük çabalar, büyük ölçüde başarısız olmuştur, çünkü programlar mevcut okul kültürünün gerçekliklerine, belirli toplulukların değerlerine veya Amerikan devlet okullarının genel bağlamına duyarlı bir biçimde tasarlanmamıştır. Anderson (1983) medya akademisyenlerinin, okul yönetimlerinin, yöneticilerin, öğretmenlerin, öğrencilerin ve anababaların gerçeklerini yadsıma eğilimini güçlü bir biçimde eleştirmiştir. Medya okuryazarlı̆̆ danışmanların yardımıyla sunulur, yöneticiler tarafından okul bölgesi içinde korunur, öğretmenler, öğrencilerin ve anababaların isteklerinin baskısı altında sorumluluklarını basite indirgemeye başladıkça da canlılığını kaybeder" (Anderson, 1983, s. 327).

Medya okuryazarlı̆̆ 1 eğiticileri, az sayıda okul reformunun, "okulların yaygın sosyal güç sistemini yeniden üreten derin taahhüdü"ne karşı durabileceği anlayışıyla çalışmaktadırlar (Aronowitz ve Giroux, 1991, s. 181). Amerikan devlet okulları, önümüzdeki yirmi yıl içerisinde medya okuryazarlığının gerektireceği oldukça dramatik bir yönde değişme eğiliminde midirler? Örneğin, 10. sınıfta sekiz klasik romanı okumak yerine, kaç topluluk, öğrencilerin dört kitap okuyup, iki film inceleyip, bir haber dergisi ile bir internet sitesini analiz etmeleri uygulamasını kabul edecektir? Kamu eğitiminde değişiklik yapma zorluklarının ışığı altında, medya eğitimini en iyi yaygınlaştıracak alanlar, okul sonrası programlar, yaz kampları, dini eğitim programları, kütüphane ve önleme programları, topluluk-temelli örgütler ve evde anababa rehberliğidir. $\mathrm{Bu}$ programlar, son yıllarda Kuzey Carolina'da ve Los Angeles'da düzenlenen iki ulusal medya okuryazarlığı eğitimi konferansında katılımcıların yaklaşık \% 40'ını oluşturmuş olan çok sayıda doğrudan okulda çalışmayan eğitimcinin katılımıyla son 5 yılda örnek bir gelişme göstermiştir.

Ancak pek çok eğitimci, eyalet düzeyinde ve yerel düzeylerde yapılan son müfredat reformu çabalarında medya eğitimi için artan bir destek için aciliyet durumu görmektedir. Medya okuryazarlığ 1 kavramları, 15'den fazla eyalette müfredat taslakları içinde yer almış durumdadır. Massachusetts'de, eyaletin İngiliz dili-sanat müfredatı, medya okuryazarlığını, etkili öğretimin 10 ilkesinden biri olarak belirlemektedir. Buna ek olarak, ilköğretim düzeyindeki eğiticiler ve ortaöğretim düzeyinde dil sanatları, sosyal bilgiler, sağlı, fen, müzik ve sanat alanlarında öğretim yapanlar için düzenlenen öğretmen eğitimi programlarının sayısı, halen az olmakla birlikte, artmaktadır. Süregiden çabalar, birçok Amerikan bölge okulunda yerli yerine oturmuş durumdadır. Medya 
eğitimine olan ilgi, yaygın eğitim örgütlerinde ve içlerinde Ortaöğretim Okul Yöneticileri Ulusal Birliği (National Association of Secondary School Principals) ve Amerikan Çocuk Hekimliği Akademisi'nin (American Academy of Pediatrics) de yer aldığ uzmanları arasında da gelişmektedir.

Medya okuryazarlığı kavramlarını müfredatla birleştirmeye başlamış olan birçok eğitimci, bölge düzeyinde işleyen örgütlü ve sistematik bir sürecin parçası değildir. Bunun yerine, bu eğitimciler, bu kavramları, kendi kendilerine, medya hakkında çeşitli okumalar yaparak, derslere devam ederek, personel geliştirme programlarına katılarak, meslektaşları ile konuşarak ve onları gözlemleyerek bir şeyler öğrenmek yoluyla edinmişlerdir. Tabandan gelen böyle bir hareket, medya okuryazarlığ1 hareketi için önemli bir enerji kaynağını temsil etmektedir. Parçalı olmasına ve niteliği açısından sıklıkla değişken olmasına rağmen, bu yaklaşım, Amerikan okullarındaki 57 milyon çocuğun ve gencin hayatlarına bu tür fikirleri taşımanın tek pragmatik yolu olabilir.

\section{Medya Okuryazarlı̆̆̆ Özelleşmiş bir Konu Olarak mı Öğretilmelidir, yoksa Mevcut Konuların Bağlamı İçine mi Yerleştirilmelidir?}

Esas olarak her eğitimci, medya okuryazarlığı kavramlarının müfredat içine yedirilmesinin değerini takdir eder. Medya metinleri, içeriği aktarmak için fen, sosyal bilgiler, tarih, sanat ve edebiyat ögretiminde kullanılmaktadır. Ancak sınıfta kullanılan metinler (örneğin, kitaplar, video kasetleri, bilgisayar programları) bilgiyi taşıma işlevleri ötesinde ender olarak dikkate alınmaktadırlar. Medya okuryazarlığı kavramları görüşünü tüm müfredat için ve bütünleştirici bir biçimde öne sürenler, metinleri sorgulama objeleri olarak kullanmanın önemini (Kress, 1992) ve disiplinler ve konular arasındaki bağlantıları değerlendirmek için çok boyutlu firsatlar olarak medya çözümlemesinin ve üretim etkinliklerinin değerini (Bevort ve Thierry, 1997; Davison, 1992; Erstad, 1997; Richards, 1992) belirtmektedirler.

Örneğin, lisedeki bir tarih öğretmeni, 1910'dan bu yana Asyalıların medyadaki imgelerinin analizi yoluyla medya okuryazarlığı kavramlarını ele almıştır. Bir İngilizce öğretmeni, öğrencileri bir kitap için pazarlama kampanyası hazırlamaya ve yapıştırmalar, basılı reklamlar, video promosyonları, grafikler, radyo reklamları ve diğer medya mesajları yaratmaya davet etmiştir. Bir 9. sınıf fen bilgisi öğretmeni, öğrencilerin, ExxonValdez çevre felaketi ile ilgili olarak biri Jacques Cousteau, diğeri de Exxon tarafindan üretilen iki farklı belgeselin kare kare görsel analizini yapmalarını sağlamıştır. Medya okuryazarlığı kavramlarının bu uygulamalarında, medya biçimsel olarak incelenmemiş, medya metinlerinin çözümlenmesinin ve medya mesajlarının yaratımının, geleneksel disiplinlerin dersle ilgili çalışmalarının bileşenleri (parçaları) olduğu vurgulanmıştır. $\mathrm{Bu}$ yaklaşım, çalışmaları yapan öğretmenlerin niteliksiz olmaları durumunda analiz ve üretimi sıradanlaştırmak riskini taşısa bile, beraberinde öğrencilerin medya çözümlemesi ve üretimi etkinlikleriyle karşılaşmaları potansiyelini taşımaktadır.

Medya okuryazarlığının ayrı bir konu olarak öğretilmesi gerektiğini savunanlar, temelde, eğitimcileri gözlemlemenin, okullarda çalışmanın ve sınıf pratiği gerçeklerine 
yakın olmanın bir sonucu olarak, pragmatik bir seçenek olmasından dolayı bu fikre varmaktadırlar (Kress, 1992). Öğretmeni sınıfta kötü bir medya okuryazarlığı etkinliği yaptırırken seyretmek, Lemish ve Lemish'in (1997) "kötü medya okuryazarlığ 1 uygulaması" (media literacy malpractice) olarak adlandırdı̆̆ 1 (s. 225) üzücü bir yaşantıdır. Rochester'da (New York) yapılan bir konferansta, İngiliz Film Enstitüsü'nden Cary Bazalgette, medya okuryazarlığı öğretmen eğitimlerinin, öğretmenlerin uygulamaları üzerindeki etkisi üzerine resmi olmayan bir tahminde bulunmuştur. $\mathrm{Bu}$ tahmin, onun, öğretmen eğiticisi olarak deneyimlerine dayanmaktadır. Medya eğitimi eğitimlerine katılan 100 öğretmenden 40'ı hiçbir şey yapmayacak, 25'i ortalama olarak iyi, 10'u yaratıcılık açısından üstün ve 25 'i de utanç verici, tehlikeli ya da sadece zaman kaybı olan bir şeyler yapacaktır.

Medya okuryazarlığı kavramlarını müfredatla bütünleştirme çabası, toplam olarak, öğrenme ve öğretmenin artışı ve canlılı̆̆ ya da kilit kavramların anlaşılmaz bir biçimde sunulmasıyla sonuçlanabilir. Medya okuryazarlığı kavramlarının müfredat içerisine yayılmasıyla, "medya eğitimi, her konunun her zaman az ya da çok ilişkili bir biçimde, ekstra değer verilmeyerek, kıyısında olacaktır” (Kress, 1992, s. 200). Bir konunun ya da becerinin müfredata yayılmış olarak geliştirilmesi gerektiğinde, sonuç "görülmezlik" olabilir (tırnak işaretleri çevirmen tarafından konmuştur). Ancak, medya okuryazarlığında özel bir seçimlik ders, şu anda Amerikan okullarında okuyan 57 milyon öğrencinin çok küçük bir bölümüne sağlanacaktır.

\section{Medya Okuryazarlığı Giriş̧imcileri Medya Kuruluşları Tarafından Maddi Olarak Desteklenmeli midir?}

Son yıllarda, gittikçe artan sayıda medya şirketi, öğretmenler için medya okuryazarlığı uygulamalarını da içerecek biçimde, teknolojinin ve medyanın eğitimde kullanımını ele alan programlar geliştirmiş durumdadır (Kamil, 1996). Örneğin, bazı topluluklarda, yerel kablo erişimi sağlayıcıları, topluma dönük yayınlarda kullanılacak video kasetlerin üretilmesi için doğrudan doğruya eğitimcilerle ve öğrencilerle çalışmaktadırlar. Amerika Vakfı Gazete Birliği (The Newspaper Association of America Foundation), öğrencilere, yerel gazeteleri medya okuryazarlığ 1 kavramlarını kullanarak analiz etmelerinde yardımc1 olmak için müfredat materyalleri üretmiştir. Cable in the Classroom dergisi, sık sı, öğretimlerinde medya okuryazarlığı kavramlarından yararlanan öğretmenlerin çabalarını vurgulamaktadır ve bu dergi, okullara, kablo işletimcileri tarafindan yaygın bir biçimde dağıtılmaktadır. $K N O W-T V$, basılı ve video halindeki materyallerle birlikte öğretmen eğitimi müfredat kaynă̆ıdır. Bu kaynak, öğretmenlerin, sınıfta, kurgusal olmayan televizyon programcılığını çözümlemelerine yardımc1 olmakta ve The Learning Channel tarafindan desteklenmektedir. KNOW-TV, 1995'de Kamu Hizmeti Programcılığı ACE Altın Kablo ödülünü kazanmıştır. Bu alanda en iyi bilinen kaynak, Ulusal Anababa-Öğretmen Birliği (National Parent-Teacher Association) ve Ulusal Kablolu Televizyon Birliği (National Cable Television Associaton) tarafından desteklenen Aile ve Topluluk Eleştirel İzleme Projesi'dir (Family 
and Community Critical Viewing Project). Bu proje, medya okuryazarlığının temel kavramlarını medyada şiddetin incelenmesi konusu ile birbirine bağlayan bir anababa eğitim programıdır. Bugüne kadar Amerika Birleşik Devletleri'nde yaklaşık 100.000 anababaya ulaşmıştır. Bütün bunları biraraya getirince, bu çabalar, okullarda medyanın eleştirel bir biçimde çözümlenmesine ilişkin stratejileri öğrenmek için oldukça düzenli ve yaygın öğretmen eğitimi fırsatları sunmaktadır.

Amerika Birleşik Devletleri'nin, medya eğitimini savunabilecek ve sağlayabilecek İngiliz Film Enstitüsü (İngiltere) ya da Kanada Ulusal Film Kurulu (Kanada) ile karşılaştırıldığında, ulusal düzeyde kültürel örgütler ya da hükümet kuruluşları açısından eksikleri bulunmaktadır. Daha da endişe verici olan, merkezileşmemiş, iyi örgütlenmemiş ve değişken nitelikteki öğretmen eğitimidir. $\mathrm{Bu}$, Amerikan okullarında çalışmakta olan yaklaşık 3 milyon öğretmene sürekli eğitim sağlamak için gerekli olan düzenli ve çok eyaletli girişimleri geliştirmeyi zorlaştırmaktadır.

Bazı savunucular ve eleştirmenler, kablolu televizyon ve gazete endüstrisinin, eğitimcilere medya analizine ve üretimine ilişkin araç, bilgi ve pedagojik stratejiler sağladığ1 için alkışlanması gerektiğini belirtmektedirler. $\mathrm{Bu}$ görüşe göre, medya kuruluşlarının, insanların bir tüketicilik becerisi olarak medya hakkında kritik düşünmelerine yardımcı olmak yönünde toplumsal sorumlulukları vardır. Ayrıca, medya kuruluşlarının fonlarına katkıda bulunarak elde edebilecekleri kâr, programları hakla ilişkiler kampanyalarının bir parçası ya da hükümet düzenlemelerine karşı bir kalkan olarak kullanmanın potansiyel tehlikelerinden daha ağır basmaktadır.

$\mathrm{Bu}$ yöndeki eleştiriler, medya endüstrisinin, zekice, maddi bakımdan desteklenmeyen ve materyal konusunda bedava olan her şeyin üstüne atlayacak kadar umutsuz olan eğitimcileri yararlandırdığını vurgulamaktadır. Bazıları, medya kuruluşlarının, kendi amaçlarına hizmet etmek için, etkili bir biçimde, medya okuryazarlığ hareketini kendileri belirleyerek ve kamuoyunun medya eleştirisinin hiçbir şekilde yüksek sesli, rahatsız edici ve keskin olmamasını sağlayacak biçimde yumuşatarak, anti-medya konumunu aldıklarına inanmaktadır (Cowrie, 1995; Montgomery, 1997).

\section{Gelecekteki Tartışma Konuları}

Medya okuryazarlığı hareketinin geleceği, kendi aralarında topluluk temelli bir sözbirliğini geliştirmek için medya okuryazarlığına ilgi duyan çeşitli eğitimci gruplarının yeteneğine bağlı olacaktır. Uygulama yoluyla elde edilen kanıtların niteliği, okul temelli medya okuryazarlığı yaşantıları ve akademik disiplinlerden gelen kuramsal bilgiler, bu büyük tartışmaların çözülmesini etkileyecektir. Halihazırda, medya okuryazarlığı, hâlâ, farklı eğitim felsefeleri, kuramları, çerçeveleri, uygulamaları, ortamları, yöntemleri, hedefleri, amaçları ve sonuçlarından oluşan geniş bir spektrumu olan bir şemsiye kavramdır. Bu yazıda belirlenen sorunlara ilişkin, medya okuryazarlığı eğitiminin yer 
aldığ1 belirli ortam ve çevrelere bağlı olarak birçok potansiyel doğru cevap var gibi görünmektedir.

Her zaman olduğu gibi, burada da bir paradoks vardır: Bakışaçılarının ve medya okuryazarlığı eğitimcilerinin yaklaşımlarının çeşitliliği, gerçekten de, medya-doygun toplumda medya metinlerinin eleştirel bir biçimde çözümlenmesinin temel bir yaşam becerisi olduğu düşüncesinin geniş gücünü ve önemini yansitan bir güç ve yaşam kaynağıdır. Ancak aynı başdöndürücü perspektif dizisi, sözbirliğine ulaşma yeteneksizliği, eğitimcileri, eylemcileri ve akademisyenleri, birlikte çalışma çabasından uzaklaştırarak savunuculuğa ve pusuya düşürmeciliğe ittiği için, felç edicidir. Eğitim tarihi, eğitimciler ve akademisyenler arasında kutuplaşmaya ve bölünmeye yol açan bu tür hata örnekleriyle karmakarışıktır; dolayısıyla, zengin düşüncelerin ve güçlü çabaların çokluğuna karşın, yeni filizlenen medya okuryazarlığı hareketinin sekteye uğrayabileceğini ve birbiriyle rekabet halindeki çıkar gruplarının büyük tartışmalar tarafından küçük kabilelere bölüneceklerini tahmin etmek şaşırtıcı olmayacaktır.

Herkes en azından tek bir ortak inancı güçlü bir biçimde benimseyebildiğinde, çeşitli tek yanlılıkları, koalisyonları, kendininkinden farklı eğitim felsefeleri olan alt grupları kabul etmek daha kolaydır. Ancak bu ortak vizyon, inanç ya da amaç ne olabilir? Medya okuryazarlığı eğitiminin merkezinde, medya metinleri hakkında soru sorma eylemi olan sorgulama pedagojisi olmalıdır. Sembolik metinlere yönelik açı, sorgulayıc1, düşünsel ve eleştirel duruş, hayatta kalışını garanti altına alan kavram olduğundan, medya okuryazarlığ 1 şemsiyesinin merkez direği olmalıdır.

Mesajların analizine ve yaratılmasına dönük okullaşma işinde, cevap bulmaktan soru sorma sürecine doğru olan değişim, temel olarak radikal bir eylemdir. Öğretmenler, bu dönüşümün tam merkezinde olmalıdırlar. Ancak maddi destekleyiciler, genellikle yetişkinlere değil, doğrudan gençlere hizmet sağlayan programlara önem vermektedirler. Daha da kötüsü, akademisyenler ve lisansüstü öğrenciler, öğretmen, kendileriyle eşit olmayan ortak olarak ya da çoğunlukla deneysel tasarımın içinde itibar bile edilmeyen bir değişken olarak kenarda durmaktayken, konu olarak öğrencilere odaklanmaya çalışmaktadırlar.

Kimse gerçek değişikliği tepeden empoze edemez. En azından uzun bir süre için... Dikkatli ve eleştirel düşünücüyü ezbere yükleme yoluyla yaratabileceğimizi ya da güçlü bir entellektüel anlayışı, mesajı yukarıdan empoze ederek ve değişmeyi, yaygınlaştırıcıların ne düşündüğü ya da hissettiği önemli değilmiş gibi yaparak kurabileceğimizi hayal etmek mantıksızdır (Meier, 1995, s. 146).

Medya okuryazarlığının geleceği, okullarda medya okuryazarlığını yaymak için temel, hatta öncelikli ortak olarak sınıftaki öğretmenlerle eğitsel çalışma yapmayı gerektiren uzun dönemli, yoğun ve entellektüel bir gelişime bağlıdır. 
Medya okuryazarlı̆̆ 1 alanında öğretmen eğitimini tasarlayan ve yayan akademisyenlerin ve eğitimcilerin, deneyimlerini, stratejilerini ve felsefelerini paylaşma fırsatları ve sağladıkları öğretme ve öğrenme deneyimlerinin niteliğini ölçmek ve değerlendirmek için yöntemler bulmaları gerekmektedir. Ulusal Telemedya Konseyi (National Telemedia Council) tarafindan yılda dört kere yayınlanan Telemedium, eğitimciler için, ilk ve orta öğretim sınıflarındaki medya okuryazarlığ 1 uygulamalarının raporlarını paylaşmak için tek yayın yoludur. Öğretmenler tarafından üretilen birçok medya okuryazarlığ müfredat programı, bölgesel ve ulusal konferanslardaki eğitici ağlarıyla paylaşılmak şöyle dursun, öğretmenin kendi okulunda bile paylaşılmamaktadır.

Ayrıca, eğer medya okuryazarlığ 1 , medya ve bilgi toplumunda iyi eğitilmiş olmanın ne demek olduğuna ilişkin farklı anlayışlara sahip akademisyenler ve eğitimciler tarafından sağlanacak canlılığın tadını çıkaracaksa, medya incelemeleriyle ilgilenen öğretim üyeleri ile eğitim alanındaki öğretim üyeleri arasında bölümler-arası çabaların desteklenmesi zorunludur. Öğretim üyeleri mümkün kılmazlarsa, lisanüstü çalışma yapan öğrenciler, medya incelemeleri ve eğitim alanları arasındaki potansiyel olarak zengin bağlantıları keşfedemezler.

Medya okuryazarlığ 1 hareketi, farklı perspektiflere, felsefelere, yöntemlere ve öğretim stratejilerine yüksek düzeyde saygı ve hoşgörü duyulmaksızın, Amerikan devlet okullarına girmeyi umut edemez. Buna, sorgulama pedagojisini (medya okuyazarı olmanın ne demek olduğunun merkezinde yer alan "izlediğiniz, gördüğünüz, okuduğunuz şeyler hakkında eleştirel sorular sorma"yı sağlama) yaymaya ilişkin sözbirliği de eklenmelidir. Bu iki etmen yerleştirildikten sonra, akademisyenler ve eğitimciler, yeni doğmakta olan bu sorgulama alanında, sıradaki iki önemli aşamaya geçmeye başlayabilirler.

İlk olarak, iyi düzenlenmiş programlar, etkinlikler ve eğitsel yaşantılar aracıllı̆̆yla daha fazla eğitimciye, çocuğa ve gence ulaşarak, daha geniş çeşitlilikteki ortamlara, medya analizi ve üretimi hakkında daha fazla bilgi ve beceriyi taşıacak çabalara ihtiyaç duyulmaktadır. Bunlar, zorunlu olarak, topluluk temelli olacaktır; ancak daha çok sayıda eyaletler arası ve ulusal girişimciler de önemlidir. İkinci olarak, bu önemli izleyicilerle birlikte, medyaya ilişkin karmaşı öğrenme ve öğretme süreçlerini kestirecek, belgeleyecek, ölçecek ve değerlendirecek kuram ve araştırmaların geliştirilmesi önemlidir. Ancak bu iki tür eylemden elde edilecek kanıtlar yoluyla, sözkonusu büyük tartışmaların çözüleceği umulabilir.

\section{KAYNAKÇA}

Alvarado, M., Gutch, R., \& Wollen, T. (1987). Learning the media: An Introduction to media teaching. London: Macmillan.

Anderson, J. (1983). Television literacy and the critical viewer. In J. Bryant \& D. R. Andersn (Eds.), Children's understanding of television: Research on attention and comprehension (pp. 297-327). New York: Academic Press. 
Aronowitz, S., \& Giroux, H. A. (1991). Postmodern education. Minneapolis: University of Minnesota Press.

Aufderheide, P. (1993). National leadership conference on media literacy. Conference report. Washingto, DC: Aspen Institute.

Austin, E., \& Johnson, K. (1997). Effects of general and alcohol-specific media literacy training on children's decision making about alcohol. Journal of Health Communication, 2(1), 17-42.

Bazalgette, C. (1992a). Key aspects of media education. In M. Alvarado \& O. BoydBarrett (Eds.), Media education: An introduction (pp. 199-219). London: British Film Institute.

Bazalgette, C. (1992b). The politicsof media education. In M. Alvarado \& O. BoydBarrett (Eds.), Media education: An introduction (pp. 140-149). London: British Film Institute.

Bazalgette, C. (1997). An agenda for the second phase of media literacy development. In R. Kubey (Ed.), Media literacy in the information age (pp. 69-78). New Brunswick, NJ: Transaction.

Bazalgette, C., Bevort, E., \& Savino, J. (Eds.) (1991). New directions: Media education worldwide. London: British Film Institute.

Bertelsmann Foundation. (Ed.) (1993). Media as a challenge-Education as a task. Gutersloh, Germany: Author.

Bertelsmann Foundation. (Ed.) (1994). School improvement through media in education. Gutersloh, Germany: Author.

Bevort, E., \& Thierry, S. (1997, April). Evaluation des competences specturielles des eleves [Evaluation of students' viewing competences]. Paper presented at the UNESCO conference. Les Jeunes and Les Medias, Paris, France.

Bianculli, D. (1992). Teleliteracy: Taking television seriously. New York: Continuum.

Boihem, H., \& Emmanouildes, C. (1997). The ad and the ego. [Videotaped]. (Available from California Newsreels, 149 Ninth St. 429, San Francisco, CA 94103).

Brown, J. A. (1991). Television "critical viewing skills" education. Hillsdale, NJ: Erlbaum.

Brunner, C., \& Smith, K. (1994). The research component of the media project at the Athens Academy and a summary of findings frm the first year. In Bertelsmann Foundation (Ed.), Media as a Media as a challenge-Education as a task (pp. 184-194). Gutersloh, Germany: Bertelsmann Foundation.

Buckingham, D. (1990). Watching media learning: Making sense of media education. London: Falmer.

Buckingham, D. (1993). Chidren talking television: The making sense of television literacy. London: Falmer.

Carnegie Council on Adolescent Development (1995). Great transitions: Preparing adolescents for a new century. New York: Carnegie Foundation. 
Carnes, T. (1996, May). The news link: How my students build media literacy skills by comparing television news to newspapers. Cable in the classroom, pp.10-11.

Center for Media Education. (1997). Web of deception: Threats to children from online marketing. Washington, DC: Author.

Center for Media Literacy. (1993). Catholic connections to media literacy. Los Angeles: Author.

Citizens for Media Literacy. (1993). Get a life. Asheville, NC: Author.

Collins, R. (1992). Media studies: Alternative or oppositional practice? In M. Alvarado \& O. Boyd-Barratt (Eds.), Media Education: An Introduction (pp. 57-62). London: British Film Institute.

Cowrie, N. (1995, Fall). Media literacy's new challenge, Video and Learning, p. 1.

Cremin, L. (1990). Popular education and its discontents. New York: Harper \& Row.

Davies, M. M. (1996). Making media literate: Educating future media workers at the the undergraduate level. In R. Kubey (Ed.), Media literacy in the information age (pp. 263-284). New Brunswick, NJ: Transaction.

Davison, J. (1992). Theory in practice: Learning media concepts through practical work. In C. Bazalgette, E. Bevort, \& J. Savino (Eds.), New directions: Media education worldwide (pp. 26-30). London: British Film Institute.

DeGaetano, G., \& Bander, K. (1996). Screen smarts: Raising media literate kids. Boston: Houghton Mifllin.

Denby, D. (1996, July 15). Buried alive. New Yorker, pp. 48-58.

Dewing, M. (1992). Beyond TV: Activities for using video with children. Santa Barbara, CA: ABC Clic.

Dichanz, H. (1995). How to renew public schools by means of media. In Bertelsmann Foundation. (Ed.), School improvement through media in education (pp.173174). Gutersloh, Germany: Bertelsmann Foundation.

Eriksen-Terzian, A. (1992). Who's holding the camera? Television/video and gender representation. In C. Bazalgette, E. Bevort, \& J. Savino (Eds.), New directions: Media education worldwide (pp. 61-69). London: British Film Institute.

Erstad, O. (1997, April 2). Media literacy at a crossroad. Paper presented at the UNESCO conference. Les Jeunes and Les Medias, Paris, France.

Fraser, P. (1992). Teaching TV cartoons. In M. Alvarado \& O. Boyd-Barrett (Eds.), Media education: An introduction (pp. 345-349). London: British Film Institute.

Freedom Forum. (1994). Death by cheeseburger: High school journalism in the 1990s and beyond.Arlington, VA: Author.

Giroux, H. A. (1994). Disturbing pleasures: Learning popular culture. New York: Routledge.

Goodman, S. (1996, Fall/Winter). Media, technology and education reform: Searching for redemption in the digital age. Video and Learning, p. 1. 
Gorley, C. (Ed.). (1997). Media literacy and substance abuse. Weekly Reader (supplement).

Grahame, J. (1991). The production process. In D. Lusted (Ed.), The media studies book: A guide for teachers (pp.146-170). London: Routledge.

Greenaway, P. (1997). Media and arts education: A global view from Australia. In R. Kubey (Ed.), Media literacy in the information age (pp. 187-198). New Brunswick, NJ: Transaction.

Halloran, J. D., \& Jones, M. (1992). The inoculation approach. In M. Alvarado \& O. Boyd-Barrett (Eds.), Media education: An introduction (pp. 10-13). London: British Film Institute.

Hart, A. (1997). Textual pleasures and moral dilemmas: Teaching media literacy in England. In R. Kubey (Ed.), Media literacy in the information age (pp. 199211). New Brunswick, NJ: Transaction.

Hobbs, R. (1994a). Pedagogical issues in U.S. media education. Communication Yearbook, 17, 453-466.

Hobbs, R. (1994b, Fall). Teaching media literacy. Yo! Are you hip to this? Media Studies Journal, 8(4), 135-145.

Hobbs, R. (1996). Expanding the concept of literacy. In R. Kubey (Ed.), Media literacy in the information age (pp. 163-183). New Brunswick, NJ: Transaction.

Hobbs, R. (1998a). Media education in Massachusetts. In A. Hart (Ed.), Teaching the media worldwide (pp. 127-144). Hillsdale, NJ: Erlbaum.

Hobbs, R. (1998b). The Simpsons meet Mark Twain: Analyzing popular texts in the classroom. English Journal, 87(1), 49-51.

Hobbs, R. (1998c). Building citizenship skills through media literacy education. In M. Salvador \& P. Sias (Eds.), The public voice in a democracy at risk. Westport, CT: Preager Press.

Hobbs, R. \& Frost, R. (1997, May). The impact of media literacy education on adolescents' media analysis and news comprehension skills. Paper presented at the annual meeting of the International Communication Association. Montreal, Canada.

Jospin, L. (1992). Media education and democracy. In C. Bazalgette, E. Bevort, \& J. Savino (Eds.), New directions: Media education worldwide (pp. 212-215). London: British Film Institute.

Kamil, B. (1996). Delivering the future: Cable and education partnerships for the information age. Alexandria, VA: Cable in the Classroom.

Kress, G. (1992). Media literacy as cultural technology in the age of media. In C. Bazalgette, E. Bevort, \& J. Savino (Eds.), New directions: Media education worldwide (pp. 190-202). London: British Film Institute.

Kumar, K. J. (1992). Redefining the goals: Reflections from India. In C. Bazalgette, E. Bevort, \& J. Savino (Eds.), New directions: Media education worldwide (pp. 15-17). London: British Film Institute. 
Lambert, F. (1997, April). Pour un enseignement specifique a l'image et aux medias [Education specifically regarding images and the media]. Paper presented at the UNESCO conference, Les Jeunes and Les Medias, Paris, France.

Landa, F. (1992). Creative work with news papers. The press in the classroom. In C. Bazalgette, E. Bevort, \& J. Savino (Eds.), New directions: Media education worldwide (pp. 18-25). London: British Film Institute.

Lemish, D. \& Lemish, P. (1997). A much debated consensus: Media literacy in Israel. In R. Kubey (Ed.), Media literacy in the information age (pp. 213-228). New Brunswick, NJ: Transaction.

Lusted, D. (1991). The media studies book: A guide for teachers. London: Routledge.

Maehr, M. L. \& Midgely, C. (1996). Transforming school cultures. Boulder, CO: Westview Press.

Mahony, R. M. (1992). Film makers, film viewers: Their challenges and opportunities. St. Paul, MN: St. Paul Books and Media.

Masterman, L. (1985). Teaching the media. London: Routledge.

Masterman, L. (1997). A rationale for media education. In R. Kubey (Ed.), Media literacy in the information age (pp. 15-68). New Brunswick, NJ: Transaction.

McClure, C. R. (1996). Network literacy in an electronic society: An educational disconnect? In R. Kubey (Ed.), Media literacy in the information age (pp. 403-439). New Brunswick, NJ: Transaction.

Meier, D. (1995). The power of their ideas. Boston: Beacon Press.

Mendez, A. M., \& Reyes, M. (1991). Television versus teachers: From antagonism to creativity. In C. Bazalgette, E. Bevort, \& J. Savino (Eds.), New directions: Media education worldwide (pp. 89-94). London: British Film Institute.

Messaris, P. (1996). Visual literacy: Image, mind, reality. Boulder, CO: Westview Press.

Morduchowicz, R. (1997, April). El Diaro en la escuela. [Newspapers in the classroom]. Paper presented at the UNESCO conference, Les Jeunes and Les Medias, Paris, France.

New London Group. (1996). A pedagogy of multiliteracies: Designing social futures. Harvard Educational Review, 66(1), 60-92.

Newspaper Association of America Foundation. (1995). Messages and meaning. Reston, VA: Author.

Office of National Drug Control Policy. (1996). President's drug control strategy. Washington, DC: Author.

Piette, J. (1997, April). L'education aux medias et le developpement de la pensee critique des jeunes [Media education and the development of critical thinking skills in youth]. Paper presented at the UNESCO conference. Les Jeunes and Les Medias, Paris, France.

Piette, J. \& Giroux, L. (1996). The theoretical foundations of media education programs. In R. Kubey (Ed.), Media literacy in the information age (pp. 89-134). New Brunswick, NJ: Transaction. 
Quin, R., \& McMahon, B. (1995). Evaluating standards in media education. Canadian Journal of Educational Communication, 22(1), 15-25.

Richards, C. (1992). Acquiring a professional identity: Media studies in initial teacher training. In C. Bazalgette, E. Bevort, \& J. Savino (Eds.), New directions: Media education worldwide (pp. 79-83). London: British Film Institute.

Sandroni, J. (1992). Newspapers and literacy: The press and schools in Brazil. In C. Bazalgette, E. Bevort, \& J. Savino (Eds.), New directions: Media education worldwide (pp. 53-56). London: British Film Institute.

Scholes, R. (1987). Textual power. New Haven, CT: Yale University Press.

Silverblatt, A. (1995). Media literacy: Keys to interpreting media messages. Westport, CT: Preager.

Singer, D. G., \& Singer, J. L. (1983). Learning how to be intelligent consumers of television. In M. J. A. Howe (Ed.), Learning from television: Psychological and educational research (pp. 203-222). London: Academic Press.

Sizer, T. R. (1995). Silences. Daedelus, 124(4), 77-83.

Stafford, R. (1992). Redefining creativity: Extended project work in GCSE media studies. In M. Alvarado \& O. Boyd-Barrett (Eds.), Media education: An introduction (pp. 69-77). London: British Film Institute.

Tauzin, B. (1997, April). Keynore address presented at the media literacy conference, Lousiana State University, Shreveport, LA.

Tyner, K. (1992). The tale of the elephant: Media education in the United States. In C. Bazalgette, E. Bevort, \& J. Savino (Eds.), New directions: Media education worldwide (pp. 170-176). London: British Film Institute.

Tyner, K. (in press). Media literacy in a digital age. Mahwah, NJ: Erlbaum.

Williamson, J. (1981). How does girl number twenty understand ideology? Screen Education, 40, 80-87.

Worsnop, C. (1996). Assessing media work. Mississauga, Canada: Wright Communications. 